\title{
The Effect of Funding Liquidity on Risk Taking Behaviour of Conventional Banks
}

\author{
Susy Muchtar and Nur Mariana Samosir \\ Faculty of Economy and Business Trisakti University \\ Email: susy.muchtar@gmail.com,nurmarianas3103@gmail.com
}

\begin{abstract}
This Research aims to determine the effect of funding liquidity on risk taking behaviour. Sample used was 36 conventional banks listed on Indonesia Stock Exchange in the period 2014-2018. The sampling technique used was purposive sampling and the method analysis was panel data regression. The independent variable are funding liquidity measured by deposits, loan and size, and the control variable are gross domestic product, interest rate and unemployee, and the dependent variable are risk taking behavior. The results showed that deposits and loan has negative effect on risk taking behavior. Size, gross domestic product, interest rate and unemployee has no effect on risk taking behavior. The results of this research are expected to be the reference for companies to see the factors that influence risk taking behavior.
\end{abstract}

Keywords: deposits, funding liquidity, gross domestic product, interest rate, loan, size, unemployee.

\begin{abstract}
Abstrak: Penelitian ini bertujuan untuk mengetahui pengaruh likuiditas pendanaan terhadap perilaku pengambilan risiko. Sampel yang digunakan sebanyak 36 bank konvensional yang terdaftar di Bursa Efek Indonesia periode tahun 2014-2018. Teknik pengambilan sampel yang digunakan yaitu purposive sampling dan metode analisa yang digunakan yaitu regresi data panel. Variabel independen dalam penelitian ini adalah likuditas pendanaan yang diukur dengan deposito, pinjaman dan ukuran bank dan variabel kontrol adalah gross domestic product, tingkat suku bunga dan tingkat pengangguran dan variabel dependen adalah perilaku pengambilan risiko. Hasil penelitian menunjukkan bahwa deposito dan pinjaman memiliki pengaruh negatif terhadap perilaku pengambilan risiko. Ukuran bank, gross domestic product, tingkat suku bunga dan tingkat pengangguran tidak memiliki pengaruh terhadap perilaku pengambilan risiko. Hasil penelitian ini diharapkan dapat dijadikan acuan bagi perusahaan dalam melihat faktor-faktor yang mempengaruhi perilaku pengambilan risiko.
\end{abstract}

Kata kunci: deposito, likuiditas pendanaan, pinjaman, produk domestik bruto, tingkat pengangguran, tingkat suku bunga, dan ukuran bank.

\section{INTRODUCTION}

Banking in Indonesia according to Law No. 10 of 1998 based on its function consists of three types, namely central banks, conventional banks (State-Owned Banks, Private and Islamic Banks), and people's credit banks. The banking sector plays a major role in the 
economic progress of a country, its activities provide services to various economic and trade sectors in Indonesia. The function of banking is as a distributor of public finance from several parties who have funds against those who lack funds. In addition, the main source of income for banks is loans that are channeled to the community (Saeed and Rama, 2017).

The fundamental role of banks in the short and long term, forming a bank is indirectly closely related to liquidity (Thai Ha and Quyen, 2018). Liquidity is a measure of the ability of a financial institution to resolve all legal liabilities and is also related to the ability to increase its assets and liabilities unless the risk occurs. According to research conducted by (Abdel, 2017) liquidity risk is the inability of banks to manage potential changes or decreases in funding.

The form of public trust in banking institutions is that the funds owned by the public that are stored or saved at a bank can be withdrawn or disbursed at any time, so the banks must be able to fulfill them. Banks that have low funding liquidity, will influence managers to tend to take higher levels of risk by lowering loan standards (Acharya and Naqvi, 2012). Other research shows that banks take more risk when risk-free interest rates increase because there is greater investment in risk-free bonds, which increases the supply of liquidity on the interbank market and encourages more interbank loans (Khan et al., 2017). Funding liquidity can be measured by the ratio of deposits and loans to banking companies (Thai and Quyen, 2018).

Deposits are funds collected by banks from the public through savings, current accounts, and deposits with the aim of saving funds and receiving interest on these deposits. High deposits indicate that banks have a high source of funding to be channeled back to the public through credit, so that the balance between assets owned by liabilities that must be paid in the form of interest expense, it will not increase bank risk.

Loans are credit given to the community to be used as their capital in opening other businesses or in accordance with the requirements of the conditions set by the bank. There are 5 principles $(5 \mathrm{C})$ set by bank managers as provisions in providing credit, namely character, capacity, capital, collateral, and condition. High loan indicates that the greater amount of funds channeled to the debtor will increase the risk of the bank when the debtor is unable to meet the payment of the loan, resulting in bad credit.

Size indicates the size of a bank that is valued based on total assets owned. The larger size takes a smaller risk because the size of the bank increases the stability of the banking institution as confirmed by the results of the higher Z-Score Index (Thai and Quyen, 2018). In addition, there are other variables that affect risk-taking behavior, namely gross domestic product, interest, and unemployed.

Economic growth is measured using gross domestic product (GDP) growth rate (Messai et al., 2015). Based on previous research, the level of development of the gross domestic product will increase risk-taking behavior (Khan et al., 2017). Interest rates include macroeconomic factors that are used to determine the effect of the relationship of funding liquidity to risk-taking behavior (Thai and Quyen, 2018). Interest rates are negatively related to Z-Score or risk-taking behavior (Thai and Quyen, 2018). Based on the results of testing by (Khan et al., 2017) found that unemployees can influence risktaking behavior. An increase in unemployed will make banks consider their activities carefully. 
Restricting the problem. This study has several limitations issues discussed were the following things: (1) Companies are examined in this study is the banking sector listed in Indonesia Stock Exchange during the period 2014-2018. (2) Companies in the Banking Sector published the Annual Financial Statements (Annual Report) complete during the period 2014-2018. (3) Companies in the banking sector have the components required for variables studied were are the deposits, loan, size, gross domestic product, interest rate, and unemployee. (4) The Company did not experience any delisting in the period 20142018.

\section{THEORETICAL REVIEW}

Risk. Risk, in general, can be explained as an adverse event or deviation from the results obtained from the expected. Banking risk is the risk of bank activity or the risk of assets encountered during bank operations (Thai and Quyen, 2018). Referring to Basel II as the basis for the implementation of risk management for international banks, there are types of bank risk which are categorized as credit risk, market risk and operational risk (Ariefianto and Soepomo, 2013). The revision of Basel II became Basel III when the global financial crisis in 2007-2009 was caused by a lack of capital adequacy, high variations of RWA between banks, leverage very high and liquidity crunch. The application of Basel III contains the minimum liquidity ratio standard requirements and arrangements regarding the ratio leverage. Based on Bank Indonesia Regulation number 11/25/PBI/2009 regarding the Implementation of Risk Management for Commercial Banks, there are eight types of risks faced by commercial banks, namely: credit risk, market risk, liquidity risk, operational risk, legal risk, strategic risk, compliance risk, and reputation risk.

Risk-Taking Behavior Risk. Risk taking behavior based on market size consisting of total risk systematic and unsystematic (Chan et al., 2016). There are several different ways of measuring bank risk in the literature, namely the VaR, ES, and Z-Score methods. Value at Risk (VaR) is a standard risk measurement for bank risk management recommended by Basel II. In addition, expected shortfall (ES) is a better risk measurement than VaR and is recommended in Basel III. However, both VaR and ES only focus on individual institutional risks, and cannot adequately capture systematic risks.

Research conducted by (Ben et al., 2017) in considering bank risk is related to the probability of bank failure by using two proxies namely Non-Performing Loan Ratio (NPL) and Z-Score. Non-Performing Loan Ratio is defined as the proportion of problem loans to gross loans and states the quality of the loan portfolio. The Z-Score Index method developed by (Boyd and Runkle, 1993) is used as an indicator of the probability of bankruptcy and investigates the risk effects of the merger of a parent bank with a non-bank financial company. The Z-Score model used as a proxy for measuring bank risk-taking behavior is the sum of ROA with the ratio of equity to total assets divided by the standard deviation of ROA.

ROA or return on assets is the ratio of the measurement results of net income divided by total assets, E/TA, which is a ratio that measures the large proportion of the company's assets that are charged by own capital from investors and company owners. The standard deviation of ROA shows a gap of a greater gain or loss and a common risk measure or standard deviation (Prasetyo, 2013). The Z-Score measurement results thus show the 
probability of a bank far from bankruptcy. Banks are said to be far from insolvency when the Z-Score results in> 0 . Higher Z-Score values indicate greater banking stability (Li and Malone, 2016).

Higher Z-Score results indicate that the bank probability of failure is low (Delis et al., 2012). Banks with higher risk-taking thus produce lower Z-Scores less efficient in capital allocation and project financing. Inefficient allocation of capital can result in a decline in the company's financial condition (financial distress) resulting in bankruptcy or liquidation. Financial distress refers to when a borrower (individual or institution) is unable to meet the payment obligations to the Bank as a lender. The need for credit analysis known as 5C (character, capacity, capital, collateral, and condition) in considering decisions on the eligibility of granting credit to borrowers in order to minimize payment failures (Zaki et al., 2011).

Funding Liquidity. Funding liquidity is referred to as the ability to collect cash in a short time. Funding liquidity can also be defined as the ease of an institution in obtaining funding (Dahir et al., 2018). Measurement of funding liquidity are deposits and loans whose data can be obtained through annual reports or financial reports in each of the banks that have been published. Another study conducted by (Andreou et al., 2016) empirically investigated the impact of managerial ability on the creation of bank liquidity and risktaking behavior, the results showed that bank managers with the higher ability create more liquidity and take more risk. When banks have high funding liquidity, they tend to take higher risks, such as increasing the volume of loans by reducing the interest rate on loans (Acharya and Naqvi, 2012).

Deposits. The definition of deposits based on the dictionary of Bank Indonesia is deposits which withdrawals can only be done at a certain time based on the agreement of the customer with the bank. Deposits are included in the liability side of a bank balance sheet obtained from a third party funds account (DPK). Third-party funds in conventional banks consist of current accounts, savings, and deposits in the banking financial statements. Requests by depositors for funds that have been saved can occur at unwanted times, that is, when payments for loans given are uncertain by the debtor or low funding liquidity (Cornett et al., 2011). Deposit measurement is the ratio between total customer deposits and total assets (Thai and Quyen, 2018).

Based on a study conducted by (Khan et al., 2017) in measuring deposits with the result that very high savings would encourage managers to take more risks. This is because if there are deposit flows at the incoming bank will increase the risk when the bank is unable to bear the interest expense that must be paid. Because the funds raised have been distributed in the form of credit and the debtor is unable to repay the loan, so the company's funds flow becomes illiquid.

There are other research differences that argue that funding liquidity risk that measures deposits is negatively correlated with bank risk-taking behavior on the Z-Score results (Thai and Quyen, 2018). This explains that if the public savings in the bank are high enough it will produce a high source of funding as well. Owned funds can be channeled to the public in the form of credit so as to create liquidity, the risk-taking of banks is low because banks can pay interest expenses to customers from the acquisition of credit payment funds. 
Loans. Loans based on the dictionary of Bank Indonesia can be defined as a provision of money by banks that will be given to other parties or lending based on an agreement and oblige the borrower to repay the debt along with interest on the loan within the specified time period. Loans are on the side of the bank's balance sheet assets for which data is obtained in the banking financial statements. Measurement of loans can use the ratio of NPL (Non-Performing Loans), while the measurement of loans in this study is the ratio of total loans and total assets (Thai and Quyen, 2018).

The test results obtained that the ratio of total loans is positively related to Z-Score significantly (Thai Ha and Quyen, 2018). This explains that the higher proportion of loans provided to the public will increase risk. Credit risk will arise when debtors are unable to meet repayments on loans, causing banks to not be able to channel customer funds back on deposits.

Other research results also stated by (Baselga et al., 2015) show a negative correlation between the relative percentage of loans in bank assets and their risks. The relatively greater proportion of loans in bank portfolios, when combined with greater liquidity risk, will result in the inability of banks to reduce liabilities in the near future or to fund increases in the assets side of the balance sheet (Trujillo, 2013).

Size. Bank sizes is an important feature of a bank in trying to understand the scale of operations that can help manage risk better. Bank measures analyze the credit market in an effort to understand the effects of financial reforms on competition and risk-taking incentives from banks. Bank size is measured using the natural logarithm of total assets (Chan et al., 2016). Large banks have great potential to diversify and reduce their risk. It may also be more sensitive to market movements than banks that have a small size (BenJabra et al., 2017).

Based on the results of (Williams, 2014) research that size is positively correlated with risk-taking behavior with Z-Score as a measurement tool. Large banks will tend to be aggressive in extending credit to risky customers and channeling large funds over a long period of time, due to the existence of a deposit guarantee by the Indonesia Deposit Insurance Corporation. There is a widespread theory that larger banks tend to be riskier because of moral problems (De Jonghe, 2010).

The size of the bank also has a significant negative impact on capital which indicates that large banks have lower amounts of capital, so large banks take lower risks (Rahman et al., 2015). The results of other studies indicate an inverse U-shape relationship between size and risk-taking behavior. The size of large banks with higher growth, tighter capital requirements and greater transparency of financial statements will take on lower risk (Houston et al., 2010). Very large banks are able to withstand the impact of interest rates on non-performing loans, because non-performing loans may be a result of systemic risk and not higher risk-taking (Delis and Kouretas, 2011).

Gross Domestic Product. The results of research by (Messai et al., 2015), show that economic development is known by measuring using Gross Domestic Product (GDP). Measurement of Gross domestic product (GDP) namely the total market value of all final goods and services produced in a country at a time (Alper et al., 2012). According to research by (Al-Harbi, 2017), gross domestic product (GDP) can be defined as a measure 
of a country's health and is also used as an indicator of the business cycle. GDP is the main indicator of economic growth that shows the level of productivity of a country (Adeusi et al., 2014).

Based on research explained by (Thai and Quyen, 2018) in Vietnam that the level of GDP growth will increase the risk-taking behavior of banks at a significant level of $1 \%$ which means there is a positive relationship between variables. Higher GDP growth driven by high levels of speculative loans funded by banks is more likely to increase bank risk (especially if funded by large short-term foreign debt.

Unlike the results of an investigation stated by (Altunbas et al., 2010) that the GDP variable is negatively related to risk-taking behavior. These results explain that the state of the economy, or gross domestic product, the better will increase net income expected by the bank, thereby reducing the credit risk of loans granted to the public and increase the strength of the bank.

Interest Rate. The interest rate deposits banks are affected based on the number of deposits by households and companies as well as the demand for deposits by banks. The existence of demand for deposits by banks shows that there are opportunities for banks to increase loans which can cause an increase in deposit rates to attract new deposits and finance new loans (David et al., 2017). Bank interest can be income for the bank that is obtained from the debtor on the distributed credit, besides that bank interest becomes an expense that must be settled and given to the customer.

Changes in interest rates to bank risk-taking are positively correlated (Altunbas et al., 2010). This explains that the high application of interest rates by Bank Indonesia will increase the credit risk of loans that have not been paid, then the manager takes the decision to reduce lending rates so as to avoid bad credit and does not affect the financial stability of the bank. Low-interest rates will reduce the credit risk of unpaid loans.

Interest rates are negatively related to Z-Score or risk-taking behavior (Thai and Quyen, 2018). The application of low-interest rates will trigger banks to tighten requirements in the demand for credit from the public in order to create liquidity. This means that an environment with low-interest rates increases bank assets that are riskrelated and changes the composition of the Eurozone bank portfolio towards risky positions.

Unemployee. Unemployment rate can be defined as a mismatch between labor supply to labor demand, as well as the unemployment rate can be seen from the demand side and offerings (Puspadjuita, 2017). On the demand side it can be caused by a lack of aggregate demand, does not require a large number of workers. Meanwhile, the supply side results from imperfections in the labor market. It can be concluded that the lack of information about employment opportunities, which causes a person to takes a long time to get a job, and consequently increase unemployment.

Research by (Thai and Quyen, 2018) found that unemployment had a significant positive correlation between the unemployment rate and bank risk. The rising unemployment rate makes bank managers take the decision to take high risks because bank funding sources from third parties are decreasing and funding liquidity is low. If that happens, the decision made by the manager is to increase deposit rates so that people are interested in depositing funds. 
Research conducted by (Bofondi and Ropele, 2011) revealed that an increase in unemployment had a significant negative impact on the quality of loan portfolios for a sample of Italian banks during the 1990-2010 period. A decrease in the unemployment rate indicates the number of opportunities for existing human resources to work or set up businesses to generate income. Setting up a business requires substantial funds so that creditors make loans to banks and banks will provide certain conditions in granting credit to avoid payment defaults. Thus, bank managers take high risk-taking behavior by raising loan rates to reduce the amount of credit given to the public.

Conceptual Framework. Society is in dire need of financial institutions to save funds and borrow funds to meet their needs. Providing sufficient funds for their withdrawal needs at a bank will create high funding liquidity at the bank. The measurement of liquidity in the (Thai and Quyen, 2018) research uses deposits, loans, and size.

The relationship of funding liquidity variables to risk-taking behavior can be measured using macroeconomic factors, namely the growth rate of gross domestic product, interest rate, and unemployee (Thai and Quyen, 2018).

Figure 1. Conceptual Framework

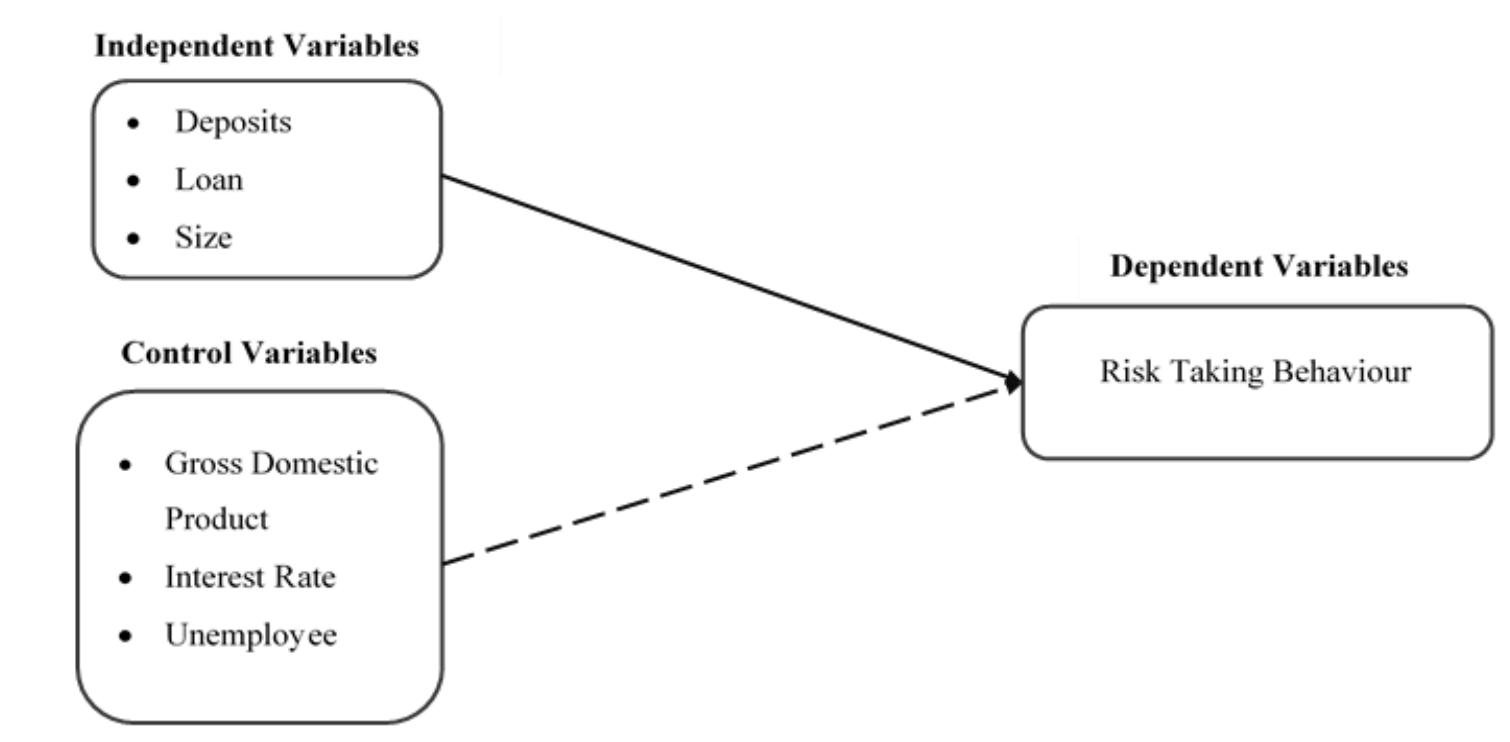

\section{Hypothesis Development}

The effect of deposits on risk-taking behavior. Based on the assessment produced by (Khan et al., 2017) in measuring deposits that very high deposits will encourage managers to take more risks, meaning that there is a positive correlation between deposits and risktaking behavior. Other research also states there is a positive relationship between the two variables in the study of (Acharya and Naqvi, 2012), namely deposits high will make managers take high decisions risk-taking behavior. Meanwhile, another study by (Thai and Quyen, 2018) argues differently that funding liquidity risk which measures deposits is negatively correlated with risk-taking behavior bank on Z-Score results. Likewise, research produced by (Anginer et al., 2014) that banks that rely more on deposits will have 
lower risks, meaning there is a negative relationship. Based on the above statement, thus formulated the following hypotheses:

H1: There is influence between deposits to risk-taking behavior.

The effect of loans on risk-taking behavior. The bank provides liquidity to borrowers (loans provided), but the loan includes assets that are relatively illiquid for banks. The ratio of total loans and total assets is positively related to risk-weighted assets (ATMR) which shows that more bank loans are usually riskier (Khan et al., 2017). The same investigation results also stated that the ratio of loans is positively related to Z-Score significantly (Thai and Quyen, 2018). However, other research shows that there is a negative relationship between a high proportion of loans, hence the possibility of a low Z-Score result (TrujilloPonce, 2013). The same study was carried out by (Baselga et al., 2015) that there is a negative influence of loans on risk-taking behavior. Based on the above statement, then formulated the following hypotheses:

H2: There is influence between loan to risk-taking behavior.

The effect of size on risk-taking behavior. Based on the results of research by (Williams, 2014) that size firm is positively correlated risk-taking behavior with the bank with ZScore as a measurement tool. Large banks take smaller risks because bank size increases banking stability as shown by higher Z-Score results (Thai and Quyen, 2018). In addition, size also has a significant negative impact on capital and on risk, so that large banks take lower risks (Rahman et al., 2015). The results of other studies suggest that there is an inverse U-shape relationship between size and risk-taking behavior. Based on the statement above, the following hypothesis is formulated:

H3: There is influence between size to risk-taking behavior.

The effect of gross domestic product on risk-taking behavior. Based on research stated by (Thai and Quyen, 2018) in Vietnam that there is a positive relationship between the growth of gross domestic product on risk-taking behavior. Other research also found that growth gross domestic product will increase risk-taking behavior which means there is a positive relationship on both variables (Williams, 2014) and (Anginer et al., 2014). Different study results stated by (Altunbas et al., 2010) and (Agoraki et al., 2011) that the variable gross domestic product is negatively related to risk-taking behavior. Based on the above statement, then formulated the following hypotheses:

H4: There is influence between gross domestic product to risk-taking behavior.

The effect of interest rate of risk-taking behavior. Changes in interest rates to risktaking behavior of banks are positively correlated (Altunbas et al., 2010). Low-interest rates will reduce the credit risk of unpaid loans. In addition, other research on interest rates that negatively related to Z-Score or risk-taking behavior (Thai and Quyen, 2018). Another research result stated by (Delis and Kouretas, 2011) that there is a negative correlation between the interest rate and risk-taking behavior in European banks. Based on the statement above, the following hypothesis is formulated:

H5: There is influence between interest rate to risk-taking behavior. 
The effect of unemployee on risk-taking behavior. Another factor that is unemployed is also tested in research to determine the effect of risk-taking behavior bank. The results of the study tested by (Khan et al., 2017) states that unemployees have a direct positive and significant impact on risk-taking behavior. The same research results also found that unemployees are positively related to risk-taking behavior (Thai and Quyen, 2018). Another study conducted by (Bofondi and Ropele, 2011) states that an increase in unemployee has a significant negative impact on the quality of loan portfolios for a sample of Italian banks during the 1990-2010 period. The same study was stated by (Louzis et al., 2012) that unemployees have a negative impact on risk-taking behavior. Based on the statement above, the following hypothesis is formulated:

H6: There is influence between unemployee to risk-taking behavior.

\section{METHODOLOGY}

Research Design. The research design used was hypothesis testing, to test the effect of the independent variables namely deposits, loans and size and the effect of control variables namely gross domestic product, interest rate and unemployee on the dependent variable, risk-taking behavior. This study analyzes banking companies listed on the Indonesia Stock Exchange during the period 2014-2018. The analytical method used is panel data regression with a measurement tool used to process data, the Eviews software 9.0 .

Variables and Measurements. There are independent, control and dependent variables in this study. The independent variables are deposits, loans, and size, the control variables are gross domestic product, interest rate, and unemployee. The dependent variable in research is risk-taking behavior.

Table 1. Variable Measurement

\begin{tabular}{|c|c|c|c|}
\hline $\begin{array}{l}\text { Variables } \\
\text { Type }\end{array}$ & $\begin{array}{l}\text { Variables } \\
\text { Name }\end{array}$ & Variables Measurement & Source \\
\hline $\begin{array}{l}\text { Dependent } \\
\text { Variables }\end{array}$ & $\begin{array}{l}\text { Risk Taking } \\
\text { Behaviour }\end{array}$ & Z-Skor $=\frac{\text { ROA }+\mathrm{E} / \mathrm{TA}}{\sigma \mathrm{ROA}}$ & \multirow{3}{*}{$\begin{array}{l}\text { (Thai and Quyen, } \\
\text { 2018) }\end{array}$} \\
\hline \multirow{3}{*}{$\begin{array}{l}\text { Independent } \\
\text { Variables }\end{array}$} & Deposits & Deposits $=\frac{\text { Total Customer Deposits }}{\text { Total Asset }}$ & \\
\hline & Loan & Loan $=\frac{\text { Total Loan }}{\text { Total Asset }}$ & \\
\hline & Size & $\begin{array}{l}\text { Bank Size = Logarithma Natural of } \\
\text { Total Asset }\end{array}$ & $\begin{array}{l}\text { (Dahir et al., } \\
\text { 2018) }\end{array}$ \\
\hline \multirow{3}{*}{$\begin{array}{l}\text { Control } \\
\text { Variables }\end{array}$} & GDP & Gross domestic product & \multirow{3}{*}{$\begin{array}{l}\text { (Thai and Quyen, } \\
\text { 2018) }\end{array}$} \\
\hline & Interest & Interest rate & \\
\hline & Unemployee & Unemployment rate & \\
\hline
\end{tabular}

Data Collection Methods. The data used in this study are secondary data. Research data obtained indirectly or from sources that have been published by companies online through the website. Sources of data in this study were obtained from the Indonesia Stock Exchange website (www.idx.co.id), the website of the Central Statistics Agency 
(www.bps.go.id) and the website of Bank Indonesia (www.bi.go.id). Research data consisted of banking companies during the 2014-2018 period.

Sampling Method. The procedure used in this study is by purposive sampling which is a sample of companies in the banking sector that has met certain criteria. Some of the criteria are as follows: (1) Companies included in the Conventional Bank sector. (2) Banking companies that have been listed on the Indonesia Stock Exchange for the period of 2014 2018. (3) The company did not experience delisting during 2014-2018. (4) The company has the components needed for the research variable are deposits, loans, and total asset.

Table 2. Sampling Method

\begin{tabular}{l|c}
\hline \multicolumn{1}{c|}{ Explanation } & Total \\
\hline $\begin{array}{l}\text { Banking companies that have been listed on the Indonesia Stock } \\
\text { Exchange for the period of 2014 - 2018. }\end{array}$ & 45 \\
\hline Banking companies included in Syariah Banks & $(3)$ \\
\hline Banking companies included in Regional Development Banks & $(3)$ \\
\hline Banking companies have been delisted & $(3)$ \\
\hline \multicolumn{1}{c}{ Total Sample } & $\mathbf{3 6}$ \\
\hline Total Observations (5 year x 36 banks) & $\mathbf{1 8 0}$ \\
\hline
\end{tabular}

\section{THE RESULTS OF STATISTICAL TESTS}

Data Testing Methods. There are three models for testing panel data regression analysis, namely the models common effect, fixed effect, and random effect. In determining the selection of the right model to be interpreted, two testing steps are carried out namely the Chow Test and the Hausman Test.

Chow Test. Test Chow Test namely testing to see a more appropriate model between common effects or fixed effects to use. Following are the processed results with Eviews software 9.0 from the Chow Test:

Table 3. Chow Test Results

\begin{tabular}{c|c|c|c}
\hline Variables & Chi-square & Prob & Decision \\
\hline Risk Taking Behaviour & 531.108801 & 0.0000 & $\begin{array}{c}\mathrm{H}_{0} \text { is rejected, the fixed fffect } \\
\text { chosen }\end{array}$ \\
\hline
\end{tabular}

Source: panel data regression E-views 9.0

Based on table 3 of the Chow Test results, the results show that the cross-section probability value Chi-Square of $0.0000<\alpha 0.05$, then the decision obtained by the $\mathrm{H}_{0}$ is rejected so that the model used is the fixed effect. 
Hausman Test. After completing the chow test and the right model is a fixed effect, the next step is to test which model fixed effect or random effect is the most appropriate. Here are processed with software Eviews 9.0 of Test Hausman:

Table 4. Hausman Test Results

\begin{tabular}{c|c|c|c}
\hline Variables & Chi-square & Prob & Decision \\
\hline Risk Taking Behaviour & 0.000000 & 1.0000 & $\begin{array}{c}\mathrm{H}_{0} \text { accepted, the random effect } \\
\text { selected }\end{array}$ \\
\hline
\end{tabular}

Source: panel data regression E-views 9.0

Based on table 4 the results of Test Hausman, the results showed that the probability of a cross-section Statistic of $1.0000>\alpha 0.05$, then a decision that can be obtained by $\mathrm{H}_{0}$ is accepted that the model used is the random effect the model.

F Test. This test aims to see the effect of independent variables and control variables in the tested model on the dependent variable. If the sig of $\mathrm{F}<0.05$ Ho is rejected, it means that the independent and control variables have an influence on the dependent variable, so that the regression model is feasible to use and vice versa. The following are the results of the processing with Eview ssoftware 9.0 from the results of the F Test:

Table 5. F Test Results

\begin{tabular}{c|c|c|c}
\hline Variables & Chi-square & Prob & Decision \\
\hline Risk Taking Behaviour & 18.35249 & 0.000000 & Tolak $\mathrm{H}_{0}$ \\
\hline
\end{tabular}

Source: panel data regression E-views 9.0

Based on the $\mathrm{F}$ test results in table 5, it appears that the F-statistic probability produces a value of $0.000000<0.05$. Thus the results of the analysis in this study shows that jointly independent variable determinant is deposits, loans, and size, and the control variable is gross gomestic product, interest rate and unemployee influence on risk-taking behavior so that decent regression model used in this study.

Goodness Test of Fit (Adjusted $\mathbf{R}^{\mathbf{2}}$ ). This test aims to predict how much the contribution of the influence of independent variables and control variables on the dependent variable with the terms of the $\mathrm{F}$ test results in the analysis regression is significant. Following are the processed results with Eviews software 9.0 from the test results Goodness of Fit:

Table 6. The Goodnes of Fit Test Results

\begin{tabular}{c|c|c}
\hline Variables & $\mathbf{R}^{\mathbf{2}}$ & Adjusted R $^{\mathbf{2}}$ \\
\hline Risk Taking Behaviour & 0.388941 & 0.367748 \\
\hline
\end{tabular}

Source: panel data regression E-views 9.0

Based on the results of the Goodness Test of fit in table 6, the adjusted r-square value of 0.367748 is obtained. This means that the independent variables namely deposits, loans, 
and size, as well as the control variables namely gross domestic product, interest rate, and unemployee, are able to explain variations of risk-taking behavior of $36.7748 \%$ and the remaining $63.2252 \%$ explain that risk-taking behavior can be influenced by other factors not included in the model. So there is a weak relationship between deposits, loans, size, gross domestic product, interest rate, and unemployee to risk-taking behavior.

Data Analysis Method. The data analysis method used in this study is panel data regression, aimed at measuring and testing the effect of independent variables namely deposits, loans and size, and the influence of control variables namely gross domestic product, interest rate and unemployee on the dependent variable, risk-taking behavior in banking companies listed on the Indonesia Stock Exchange in the period 2014-2018. The regression model of this research was formulated as follows:

$$
\begin{aligned}
Z-\text { Skor }_{i t}= & \beta_{0}+\beta_{1} \text { Deposits }_{i t}+\beta_{2} \text { Loan }_{i t}+\beta_{3} \text { Size }_{i t}+e \mu_{t} \\
Z-\text { Skor }_{i t}= & \beta_{0}+\beta_{1} \text { Deposits }_{i t}+\beta_{2} \text { Loan }_{i t}+\beta_{3} \text { Size }_{i t}+\beta_{4} G \\
& \beta_{5} \text { Interest }_{i t}+\beta_{6} \text { Unemploy }_{i t}+e \mu_{t}
\end{aligned}
$$$$
Z-\text { Skor }_{i t}=\beta_{0}+\beta_{1} \text { Deposits }_{i t}+\beta_{2} \text { Loan }_{i t}+\beta_{3} \text { Size }_{i t}+\beta_{4} G D P_{i t}+
$$

$\begin{array}{ll}\text {ZZ-Skor }_{\text {it }} & =\text { Risk Taking Behaviour } \\ \text { Deposits }_{i t} & =\text { Deposits } \\ \text { Loan }_{\text {it }} & =\text { Loan } \\ \text { Size }_{i t} & =\text { Size } \\ \text { GDP }_{i t} & =\text { Gross Domestic Product } \\ \text { Interest }_{i t} & =\text { Interest rate } \\ \text { Unemployee }_{i t} & =\text { Unemployee } \\ \text { e }_{\text {it }} & =\text { error term }\end{array}$

\section{DISCUSSION}

\section{Statistics Descriptive Results}

Following statistical descriptive results of the research variables used:

Table 7. Descriptive Statistics

\begin{tabular}{l|c|c|c|c|c}
\hline \multicolumn{1}{c|}{ Variables } & N & Mean & Min. & Max. & Std. Dev \\
\hline Z-Skor & 180 & 24.40914 & 0.885100 & 125.9035 & 22.15351 \\
\hline Deposits & 180 & 0.751033 & 0.519400 & 0.889800 & 0.068900 \\
\hline Loan & 180 & 0.650412 & 0.401200 & 0.869500 & 0.090464 \\
\hline Size & 180 & 13.50213 & 11.82260 & 15.11290 & 0.814419 \\
\hline Gross Domestic Product & 180 & 0.050320 & 0.048800 & 0.051700 & 0.000942 \\
\hline Interest Rate & 180 & 0.060500 & 0.042500 & 0.077500 & 0.014128 \\
\hline Unemployee & 180 & 0.057140 & 0.053400 & 0.061800 & 0.003057 \\
\hline
\end{tabular}

Source: panel data regression E-views 9.0

\section{Data analysis}


Multiple Linier Regression. The analytical method used in this study is multiple linier regression with the aim to determine the funding liquidity that influence deposits, loan, size, gross domestic product, interest rate, and unemployee to risk taking behaviour. The regression model used in this study is as follows:

\section{Z-Skor = -15.17911 - 108.0349Deposits - 49.47189Loan - 1.271996Size + 2116.259GDP - 111.9503Interest + 1231.372Unemployee}

Hypothesis (T) Test. Test (T) aims to test the regression coefficients of each independent variable and control variables on the dependent variable. And to find out how much influence between deposits, loans, size, gross domestic product, interest rate, and unemployee on risk-taking behavior in banks with Z-Score measurement. If sig $\mathrm{t}<0.05$ then $\mathrm{H}_{0}$ is rejected, meaning that the independent variables and control variables have an influence on the dependent variable and vice versa. The following shows the results of the (T) test of each variable used in the study:

Table 8. T-Test Results

\begin{tabular}{l|c|c|c}
\hline \multirow{2}{*}{ Independent Variables } & \multicolumn{3}{|c}{ Dependent Variables } \\
\cline { 2 - 4 } & \multicolumn{3}{|c}{ Risk Taking Behaviour } \\
\cline { 2 - 4 } & Coefficient & Probability & Conclusion \\
\hline Constanta & -15.17911 & - & - \\
\hline Deposits & -108.0349 & 0.0000 & Significant \\
\hline Loan & -49.47189 & 0.0000 & Significant \\
\hline Size & -1.271996 & 0.7330 & Not Significant \\
\hline GDP & 2116.259 & 0.6010 & Not Significant \\
\hline Interest rate & -111.9503 & 0.3948 & Not Significant \\
\hline Unemployee & 1231.372 & 0.4516 & Not Significant \\
\hline
\end{tabular}

Based on the results of the $(\mathrm{T})$ test in table 8 , it can be interpreted the effect of each independent variable on the dependent variable as follows:

(1) Deposits produce a probability value of $0.0000<\alpha 0.05$ so that it can be concluded that significant. The magnitude of the coefficient value is -108.0349 . The results of the regression test in the study state that there is a negative influence between deposits on risk-taking behavior in conventional banking companies in Indonesia. This result is in line with research conducted by (Thai and Quyen, 2018) which states that deposits have a negative influence on risk-taking behavior using Z-Score measurements. This explains that if the public savings in the bank are high enough it will produce a high source of funding as well. Owned funds can be channeled to the public in the form of credit so as to create liquidity, the risk-taking of banks is low because banks can pay interest expenses to customers from the acquisition of credit payment funds. The same study also by (Anginer et al., 2014) that deposits negatively affect risk-taking behavior. However, it is different from the study stated by (Acharya and Naqvi, 2012) and (Khan et al., 2017) found that there is a positive influence between deposits on risk-taking behavior with Z-Score measurement. 
(2) Loan produces a probability value of $0.0000<\alpha 0.05$ so that it can be concluded that it is significant. The magnitude of the coefficient value of -49.47189 . The results of the regression test in the study stated that there is a negative influence between loans on risk-taking behavior in conventional banking companies in Indonesia. These results are in line with research by (Trujillo, 2013) and (Baselga et al., 2015) that loans have a negative influence on risk-taking behavior. This explains that a relatively large proportion of loans channeled to the public will reduce risk-taking behavior in banks when bank managers are able to properly evaluate lending. Evaluate lending by reconsidering decisions in granting loans relating to the 5C principle (character, capacity, capital, collateral and condition). Therefore, there is no risk of bad credit because the debtor is able to meet the payment of the loan. In contrast to the results of research conducted by (Thai and Quyen, 2018), (Cornett et al., 2011), and (Khan et al., 2017) states that loans have a positive influence on risk-taking behavior bank by measuring the Z-Score.

(3) Size produces a probability value of $0.7330>\alpha 0.05$ so that it is concluded that it is not significant. The results of the regression test in the study state that there is no influence between the size of the bank on risk-taking behavior in conventional banking companies in Indonesia. This is in line with the results of the study stated by (Bertay et al., 2013) that there is no relationship between bank size and risk-taking behavior. Difficult to identify the threshold size of a bank properly so that it cannot apply size restrictions on each bank. Another study by (Bhagat et al., 2015). also states that there is no size effect on risk-taking behavior. This means that controlling bank risk-taking does not refer to the size of the bank but focus on capital requirements and leverage. However, the results of this study differ in the study stated by (Williams, 2014), (Leaven et al., 2014) and (Baselga et al., 2015) that bank size has a positive influence on risk-taking behavior. Other research shows a negative relationship between bank size and risk-taking behavior by (Rahman et al., 2015) and (Houston et al., 2010).

(4) Gross Domestic Product (GDP) produces a probability value of $0.6010>\alpha 0.05$ so that it is concluded as insignificant. The results of the regression test in the study state that there is no influence between Gross Domestic Product on risk-taking behavior in conventional banking companies in Indonesia. This is in line with research by (Behr et al., 2010) that gross domestic product has no effect on risk-taking behavior. The increase in gross domestic product shows the economy and high public income, but this will make depositors prefer investment other than in banks because they expect greater returns such as in the property and stock sectors. In addition, from the debtor's side, they will make loans originating from foreign countries due to lower loan interest. However, these results are not in line with research conducted by (Thai and Quyen, 2018), (Williams, 2014), and (Anginer et al., 2014) which states that gross domestic product has a positive influence on bank risk-taking behavior that uses Z-Score measurements. However, different results from studies by (Altunbas et al., 2010) and (Agoraki et al., 2011) that gross domestic product has a negative influence on risk-taking behavior.

(5) Interest rate produces a probability value of $0.3948>\alpha 0.05$ so that it is concluded that it is not significant. The results of the regression test in the study state that there is no influence between the interest rate on the risk-taking behavior of conventional banking companies in Indonesia. These results are in line with research conducted by (Tabak et al., 2010) and (Agoraki et al., 2011) that there is no influence on the interest rate on risk-taking behavior. The interest rate has no effect on risk-taking behavior based on the high Z-score 
index of each bank, indicating that the bank is far from insolvency. So that changes in interest rates by the Central Bank will not be so influential for banks because managers who are able to manage the funds raised and funds channeled to the public so that there are no significant changes in deposit or loan interest rates, there is no risk-taking for banks. The need for efficient bank supervision to avoid loan and deposit shocks (Tabak et al., 2010). However, these results are not in line with research conducted by Altunbas et al. (2010) that the effect of interest rates positively on risk-taking behavior. Unlike the case with research conducted by (Thai and Quyen (2018), (Agur and Demertzis, 2012), (Baselga-Pascual et al., 2015), and Delis and Kouretas (2011) that interest rates have a negative influence on risk-taking behavior.

(6) Unemployee produces a probability value of $0.4516>\alpha 0.05$ so that it can be concluded that it is not significant. The results of regression tests in the study stated that there was no influence between unemployee on risk-taking behavior in conventional banking companies in Indonesia. This is in line with the research stated by (Baselga et al., 2015 ) that unemployees do not have an influence on risk-taking behavior. When someone who has just been laid off or is in a position of unemployment results in reduced income he has, so there is no courage in making loans to banks because they do not have collateral if the debtor is no longer able to meet payments on interest on the loan or the loan principal. Then, there is no effect of unemployee on risk-taking behavior in banks. Different results with research by (Thai and Quyen, 2018) and (Khan et al., 2010) that unemployees are positively correlated with risk-taking behavior. However, other research states there is a negative influence between the unemployment rate on bank risk-taking (Bofondi and Ropele, 2011) and (Louzis et al., 2012).

\section{CONCLUSION}

Managerial Implications. Based on the above conclusion, the results of this study provide managerial implications that can be used in business practices for several parties, among others:

Companies. For financial managers in making bank risk decision making, it is better to consider the influence internally and externally of banks by (1) raising funds from third parties to create high liquidity. (2) pay attention to loan requirements given to creditors to avoid bad credit. (3) managers should always review the interest rates set by Bank Indonesia regarding the interest rates on deposits and loans at each bank to avoid liquidity risk. (4) testing the z-score index in order to find out whether the bank is in a state far from insolvency or not, so that it optimizes costs to cover shortages, and takes restructuring measures to reduce debt and interest expenses.

Investors. For investors before deciding on investments or making loans at a bank, it is better to pay attention to the bank's capital adequacy, bank liquidity, deposit, and loan interest rates by looking at banking financial statement data and also measuring z-score indexes to see the results of banks at the good condition. When customers will deposit their funds will get high bank interest services and when making loans to banks will pay relatively small loan interest.

Conclusion. This study aims to identify and examine the influence of the independent variable determinant is deposits, loan, size, gross domestic product, interest rate, and 
unemployee on the dependent variable is risk taking behaviour. This study uses 36 commercial banks listed on the Indonesia Stock Exchange in the periode 2014-2018. Based on the analysis and discussion that has been done, it can be summed up as follows: (1) Deposits has a negative impact on risk taking behaviour. (2) Loan has a negative impact on risk taking behaviour. (3) Size has no effect on risk taking behaviour. (4) Gross domestic product has no effect on risk taking behaviour. (5) Interest rate has no effect on risk taking behaviour. (6) Unemployee has no effect on risk taking behaviour.

Research Limitations. Based on the results of research conducted, this study still has research limitations, namely: (1) Limited research period, namely only 2014-2018. (2) The sample used was only conventional banking companies listed on the Indonesia Stock Exchange as many as 36 companies. (3) The variables used in this study are limited, namely using variables deposits, loan, size, gross domestic product, interest rate, and unemployee to determine the effect on risk taking behavior.

Suggestions. Based on the conclusions and limitations of the research results that have been put forward, the suggestions that can be given to further researchers are as follows: (1) Future studies are expected to not only use Conventional Bank samples but add to all bank samples in Indonesia including Sharia Banks and Regional Banks. (2) Adding other independent variables to measure bank risk taking behavior such as cost efficiency, market power (Ishaq, Z., 2012). Loan to deposit ratio (LDR), inflation rate (Dahir et al., 2017). Return on assets, equity (Khan et al., 2017).

\section{REFFERENCES}

Abdel Megeid, Nevine Sobhy. (2017). "Liquidity Risk Management: Conventional Versus Islamic Banking System in Egypt." Journal of Islamic Accounting and Business Research, 8.1: 100-128.

Acharya, V., and Naqvi, H. (2012). "The Seeds of a Crisis: A theory of Bank Liquidity and Risk Taking Over the Business Cycle”. Journal of Financial Economics, 106(2), 349-366.

Adeusi, S. O., Kolapo F. T., dan Aluko, A., O. (2014). Determinants of Commercial Banks Profitability. International of Economics, Commerce and Management, Vol. 2 Issue :12, pp. 1-18. http://ijecm.co.uk/.

Agoraki, M. E. K., Delis, M. D., and Pasiouras, F. (2011). Regulations, Competition and Bank Risk-Taking in Transition Countries. Journal of Financial Stability, 7(1), 38-48. https://doi.org/10.1016/j.jfs.2009.08.002.

Agur, I., and Demertzis, M. (2012). Excessive Bank Risk Taking and Monetary Policy. European Central Bank, (1457). Retrieved from

https://www.ecb.europa.eu/pub/pdf/scpwps/ecbwp1457.pdf?e0eea99cecbbe5262be50 $71 \mathrm{c} 5 \mathrm{db} 9 \mathrm{eded}$.

Al-Harbi, A. (2017). "Determinants of Banks Liquidity: Evidence from OIC Countries". Journal of Economic and Administrative Sciences, 33(2), 164-177. https://doi.org/10.1108/JEAS-02-2017-0004.

Alper, K., Hulagu, T., and Keles, G. (2012), “An Empirical Study on Liquidity and Bank Lending". Central Bank of the Republic of Turkey Working Paper, 4. 
https://www.researchgate.net/publication/254451804_An_Empirical_Study_on_Liqu idity_and_Bank_Lending.

Altunbas, Y., Gambacorta, L., and Ibáñez, D. M. (2010). Does Monetary Policy Affect Bank Risk-Taking? Working paper series, No. 1166. https://www.ecb.europa.eu//pub/pdf/scpwps/ecbwp1166.pdf.

Andreou, P.C., Philip, D., and Robejsek, P. (2016). Bank Liquidity Creation and RiskTaking: Does Managerial Ability Matter? Journal of Business Finance and Accounting, 43(1-2), 226-259.

Anginer, D., Demirguc-Kunt, A., and Zhu, M. (2014). How does deposit insurance affect bank risk? Evidence from the recent crisis. Journal of Banking and Finance, 48, 312321. https://doi.org/10.1016/j.jbankfin.2013.09.013.

Ariefianto, M. D., and Soepomo, S. (2013). Risk Taking Behavior of Indonesian Banks: Analaysis on the Impact of Deposit Insurance Cooperation Establishment. Buletin Ekonomi Moneter Dan Perbankan, 15(3), 3-25. https://doi.org/10.21098/bemp.v15i3.66.

Baselga-Pascual, L., Trujillo-Ponce, A., and Cardone-Riportella, C. (2015). Factors Influencing Bank Risk in Europe: Evidence from the Financial Crisis. North American Journal of Economics and Finance, 34, 138-166. https://doi.org/10.1016/j.najef.2015.08.004.

Behr, P., Schmidt, R. H., and Xie, R. (2010). Market structure, capital regulation and bank risk taking. Journal of Financial Services Research, 37(2-3), 131-158. https://doi.org/10.1007/s10693-009-0054-y

Ben Jabra, W., Mighri, Z., and Mansouri, F. (2017). Determinants of European Bank Risk During Financial Crisis. Cogent Economics and Finance, 5(1), 1-21. https://doi.org/10.1080/23322039.2017.1298420.

Bertay, A. C., Demirgüç-Kunt, A., and Huizinga, H. (2013). Do We Need Big Banks? Evidence on Performance, Strategy and Market Discipline. Journal of Financial Intermediation, 22(4), 532-558. https://doi.org/10.1016/j.jfi.2013.02.002.

Bhagat, S., Bolton, B., and Lu, J. (2015). Size, Leverage, and Risk-Taking of Financial Institutions. Journal of Banking and Finance, 59(June), 520-537. https://doi.org/10.1016/j.jbankfin.2015.06.018.

Bofondi, M., and Ropele, T. (2011). Macroeconomic Determinants of Bad Loans: Evidence from Italian Banks. Questioni di Economia e Finanza (occasional papers). No. 89. https://www.bancaditalia.it/pubblicazioni/qef/2011-0089/QEF_89.pdf.

Boyd, J.H., and Runkle, D.E. (1993). Size and Performance Of Banking Firms. Journal of Monetary Economics, 31(1), 47-67. https://doi.org/10.1016/0304-3932(93)90016-9.

Chan, S. G., Koh, E. H. Y., and Karim, M. Z. A. (2016). The Chinese Banks' Directors and Their Risk-Taking Behavior: A corporate governance and finance perspective. Chinese Management Studies, 10(2), 291-311. https://doi.org/10.1108/CMS-10-20150226.

Cornett, M. M., McNutt, J. J., Strahan, P. E., and Tehranian, H. (2011). Liquidity Risk Management and Credit Supply in the Financial Crisis. Journal of Financial Economics, 101(2), 297-312. https://doi.org/10.1016/j.jfineco.2011.03.001.

Dahir, A. M., Mahat, F. B., and Ali, N. A. Bin. (2018). Funding liquidity risk and bank risk-taking in BRICS countries: An application of system GMM approach. 
International Journal of Emerging Markets, 13(1), 231-248. https://doi.org/10.1108/IJoEM-03-2017-0086.

David, I.B., Palvia, A., and Spatt, C. (2017). "Banks' Internal Capital Markets and Deposit Rates". Journal of Financial and Quantitative Analysis, Vol. 52, No. 5, Oct. 2017, pp. $1797-1826$.

De Jonghe, O. (2010). Back to the Basics in Banking? A Micro-Analysis of Banking System Stability. Journal of Financial Intermediation, 19(3), 387-417. https://doi.org/10.1016/j.jfi.2009.04.001.

Delis, M. D., and Kouretas, G. P. (2011). Interest Rates and Bank Risk-Taking. Journal of Banking and Finance, 35(4), 840-855. https://doi.org/10.1016/j.jbankfin.2010.09.032.

Delis, M. D., Tran, K.C., and Tsionas, E.G. (2012), "Quantifying and Explaining Parameter Heterogeneity in the Capital Regulation-Bank Risk Nexus". Journal of Financial Stability, 8, 57-68. https://doi.org/10.1016/j.jfs.2011.04.002.

Houston, J. F., Lin, C., Lin, P., and Ma, Y. (2010). Creditor Rights, Information Sharing, and Bank Risk Taking. Journal of Financial Economics, 96(3), 485-512. https://doi.org/10.1016/j.jfineco.2010.02.008.

Khan, M. S., Scheule, H., and Wu, E. (2017). "Funding Liquidity and Bank Risk Taking", Journal of Banking and Finance, 82, 203-216. https://doi.org/10.1016/j.jbankfin.2016.09.005.

Laeven, L., Ratnovski, L., \& Tong, H. (2014). Much Ado About Nothing: Non-Member State Status, Palestine and the International Criminal Court. Journal of International and Comparative Law, 3(2), 3.

Louzis, D. P., Vouldis, A. T., and Metaxas, V. L. (2012). Macroeconomic and BankSpecific Determinants of Non-Performing Loans in Greece: A comparative study of Mortgage, Business and Consumer Loan Portfolios. Journal of Banking and Finance, 36(4), 1012-1027. https://doi.org/10.1016/j.jbankfin.2011.10.012.

Messai, A. S., Gallali, M. I., and Jouini, F. (2015). "Determinants of Bank Profitability in Western European Countries Evidence from System GMM Estimates", International Business Research, Vol.8 No.7, pp.30-42. https://doi.org/10.5539/ibr.v8n7p30.

Prasetyo, M. I. (2013). "Analisis Pengaruh Kecukupan Modal, Kredit Bermasalah, Likuiditas, dan Marjin Bunga Bersih terhadap Risiko Bisnis (Studi pada Bank Umum Swasta Nasional Devisa)". Jurnal Aplikasi Manajemen, 11(2), 259-266. https://jurnaljam.ub.ac.id/index.php/jam/article/view/568.

Puspadjuita, E. A. R. (2017). "Factors that Influence the Rate of Unemployeement in Indonesia", International Journal of Economics and Finance, Vol. 10 No. 1, pp 140 147. https://doi.org/10.5539/ijef.v10n1p140.

Rahman, M. M., Zheng, C., and Ashraf, B. N. (2015). Bank Size, Risk-taking and Capital Regulation in Bangladesh. Eurasian Journal of Business and Economics, 8(15), 95114. https://doi.org/10.17015/ejbe.2015.015.05.

Saeed, A.-M. and Rama, M.Y.S. (2017). "Interest banking spreads in Oman and Arab GCC", International Journal of Emerging Markets, Vol. 12 No. 3, pp. 532-549. https://www.emeraldinsight.com/doi/full/10.1108/IJoEM-03-20170086 ?fullSc $=1 \& \mathrm{mbSc}=1$.

Tabak, M.B., Laiz, M.T., and Cajueiro, D.O. (2010). "Financial Stability and Monetary Policy - The case of Brazil". Working paper series 217, p.1-61. https://www.bcb.gov.br/pec/wps/ingl/wps217.pdf. 
Thai Ha, N.T., and Quyen, P.G. (2018). "The Impact of Funding Liquidity on Risk-Taking Behavior of Vietnamese Banks: Approaching by Z-score measure", International Journal of Economics and Financial Issues, Vol. 8 No 3, pp. 29-35.

Trujillo-Ponce, A. (2013). What Determines the Profitability of Banks? Evidence from Spain. Accounting and Finance, 53(2), 561-586. https://doi.org/10.1111/j.1467629X.2011.00466.x.

Williams, B. (2014). Bank risk and national governance in Asia. Journal of Banking and Finance, 49, 10-26. https://doi.org/10.1016/j.jbankfin.2014.08.014.

Zaki, E., Bah, R., and Rao, A. (2011). Assessing Probabilities of Financial Distress of Banks in UAE. International Journal of Managerial Finance, 7(3), 304-320. https://doi.org/10.1108/17439131111144487. 